\title{
ANALISIS VOLUME SALIVA YANG TERSTIMULASI PADA PECANDU GANJA DI PUSAT REHABILITASI INSYAF MEDAN TAHUN 2014
}

\author{
(ANALYSIS OF STIMULATED SALIVARY VOLUME AMONG MARIJUANA ABUSERS \\ AT INSYAF REHABILITATION CENTER IN MEDAN 2014)
}

\author{
Rehulina Ginting, Beactris Lamria \\ Departemen Biologi Oral \\ Fakultas Kedokteran Gigi, Universitas Sumatera Utara \\ Jl. Alumni No.2 Kampus USU Medan 20155
}

\begin{abstract}
Indonesia is the second largest marijuana producer in the world, there were 9000 marijuana abusers in 2007 and 1.072 marijuana abusers in North Sumatera in 2011. The abuse of marijuana causes many health problems, one of them is oral cavity problem, such as xerostomia, periodontal disease, caries, candidiasis and the changes of oral ephitelium. Those problem comes as a result of the saliva inadequacy in marijuana abusers. The aim of this study was to observe the relation between consuming marijuana and stimulated salivary volume in the Insyaf Rehabilitation Center Medan 2014. This was an observational analytic research with cross sectional design. Subjects were 40 persons which consist of 30 former marijuana abusers and 10 persons without any history of marijuana abuse as the control group. The result of this research indicated a decreasing stimulated salivary volume on former marijuana abusers compared to the control group which was $7,7623 \mathrm{ml} / 5 \mathrm{~min}$. The conclusion of this research showed a relationship between consuming marijuana and a decreasing stimulated salivary volume between former marijuana abusers compared to control group and it was affected by frequencies, duration and the time span of cessation in consuming marijuana.
\end{abstract}

Key words: marijuana, stimulated saliva, volume

\begin{abstract}
Abstrak
Indonesia merupakan produsen ganja kedua terbesar di dunia, jumlah pecandu ganja pada tahun 2007 mencapai 9000 orang dan di Sumatera Utara, mencapai 1.072 orang pada tahun 2011. Konsumsi ganja dapat menyebabkan masalah kesehatan rongga mulut seperti xerostomia, penyakit periodontal, karies, kandidiasis serta perubahan pada epitel rongga mulut. Hal ini dapat disebabkan karena kurang adekuatnya saliva pada pecandu ganja. Tujuan penelitian ini adalah untuk mengetahui hubungan mengonsumsi ganja dengan volume saliva yang distimulasi pada mantan pecandu ganja di pusat rehabilitasi Insyaf Medan tahun 2014. Jenis penelitian adalah studi observasional analitik dengan rancangan cross sectional. Subjek yang diteliti adalah sebanyak 40 orang yang terdiri atas 30 orang mantan pecandu ganja dan 10 orang tanpa riwayat konsumsi ganja sebagai kelompok kontrol. Hasil penelitian ini menunjukkan terjadi penurunan volume saliva yang distimulasi pada pecandu ganja dibandingkan dengan kelompok kontrol yaitu 7,7623 ml/5 menit. Kesimpulan penelitian ini menunjukkan adanya hubungan mengonsumsi ganja dengan penurunan volume dan saliva yang distimulasi antara kelompok mantan pecandu ganja dengan kelompok kontrol dan hal ini dipengaruhi oleh frekuensi, durasi dan lamanya berhenti mengonsumsi ganja.
\end{abstract}

Kata kunci: ganja, saliva yang distimulasi, volume

\section{PENDAHULUAN}

Ganja telah menjadi narkotika yang paling banyak diproduksi, diperdagangkan dan dikonsumsi di seluruh dunia. Ganja dikonsumsi oleh $75 \%$ pecandu narkotika di dunia. Indonesia merupakan produsen ganja kedua terbesar di dunia setelah India. Di
Indonesia, jumlah pecandu ganja pada tahun 2007 mencapai 9000 orang dan di Sumatera Utara, mencapai 1.072 orang pada tahun $2011 .^{1-3}$ Ganja merupakan tanaman Cannabis sativa yang diolah dengan cara mengeringkan bagian tangkai, daun, biji dan bunganya yang mengandung banyak resin. Ganja juga dikenal dengan nama lain yaitu cannabis, 
herb, mariyuana, ataupun weed. ${ }^{4}$

Ganja banyak disalahgunakan karena dapat menyebabkan halusinasi, euforia dan relaksasi, sehingga perlu menjadi perhatian dokter gigi dalam menangani pasien yang merupakan pecandu ganja. ${ }^{5,6}$ Ganja dapat dikonsumsi dengan berbagai cara. Dengan cara dihirup atau dihisap baik dengan dilinting kemudian dihisap seperti rokok, melalui pipa biasa, ataupun melalui pipa air yang biasa disebut dengan bong dan dengan cara dimakan ataupun diminum. ${ }^{4}$ Namun, cara menghisap atau menghirup ganja merupakan cara yang paling sering digunakan karena lebih praktis serta dapat menimbulkan efek lebih cepat., ${ }^{4,7}$ Ganja mengandung 400 substansi aktif atau semi aktif, diantaranya adalah lebih dari 60 substansi bahan kimia aktif yang disebut dengan "cannabinoid". Delta-9-tetrahydrocannabinol (THC) merupakan salah satu "cannabinoid" yang paling penting dan memiliki sifat psikoaktif. ${ }^{4,7}$

Efek THC dalam tubuh bergantung pada dosis yang diterima seseorang, dosis penggunaan THC yaitu 5-25 mg. ${ }^{7}$ Penggunaan ganja sebagai bahan medikasi telah dilarang di beberapa negara sejak abad 20, namun pada awalnya ganja dapat digunakan sebagai bahan medikasi. ${ }^{4}$ Mengonsumsi ganja dengan dosis yang tepat dapat mengobati inflamasi membran mukosa, lepra, demam, obesitas, asma, infeksi saluran urin dan batuk. Manfaat terapi dari "cannabinoid" yaitu sebagai analgesik, relaksasi otot, anti alergi, bronkodilator, neuroproteksi, bahan sedatif, antiemesis, serta menurunkan tekanan intraokular. $^{4}$

Ganja yang disalahgunakan dan dikonsumsi lebih dari dosisnya akan menimbulkan masalah kesehatan dan mempengaruhi struktur dan fungsi otak, sistem kardiovaskular, sistem pernafasan, serta sistem reproduksi. $^{2,5,-9}$ Ganja mempengaruhi sistem tubuh manusia melalui ikatan THC dengan reseptor "cannabinoid" (CB). ${ }^{5}$ Reseptor "cannabinoid" berdasarkan afinitasnya dibagi menjadi reseptor $\mathrm{CB}_{1}$ dan reseptor $\mathrm{CB}_{2}$. Reseptor $\mathrm{CB}_{1}$ dapat ditemukan di hipokampus, ganglia basal, serebelum, sistem saraf dan juga ditemukan di saluran kelenjar saliva submandibula (ductal system). Reseptor $\mathrm{CB}_{2}$ ditemukan di makrofag pada limpa, sel-sel imun, dan sel-sel asini kelenjar saliva submandibula. ${ }^{4,7,8}$

Penyalahgunaan ganja juga dapat menyebabkan masalah kesehatan rongga mulut, seperti xerostomia, penyakit periodontal, karies, kandidiasis serta perubahan pada epitel rongga mulut bahkan kanker rongga mulut. ${ }^{5-7} \mathrm{Hal}$ ini salah satunya disebabkan oleh kurang adekuatnya volume saliva pada pecandu ganja. Volume saliva yang adekuat dapat berfungsi seperti sebagai proteksi, lubrikasi mukosa, dan antimikroba bagi rongga mulut. ${ }^{10}$

Ganja dapat menyebabkan perubahan sekresi saliva. Aktivasi langsung reseptor "cannabinoid" pada kelenjar saliva submandibula saat mengonsumsi ganja dapat menginhibisi sekresi saliva pecandu ganja. Penelitian in vivo pada tikus yang dilakukan oleh Prestifilipo ditemukan bahwa THC menurunkan aliran saliva dari kelenjar submandibula. ${ }^{8}$ Selain melalui aktivasi langsung, THC yang terakumulasi di sel saraf dapat menginhibisi kerja sistem saraf parasimpatis sehingga mengurangi sekresi saliva., ${ }^{5,11}$

Penelitian ini menunjukkan hubungan antara mengonsumsi ganja dengan penurunan volume saliva yang distimulasi pada pecandu ganja di Pusat Rehabilitasi Insyaf Medan tahun 2014 dan hal ini dipengaruhi oleh frekuensi, durasi dan lamanya berhenti mengonsumsi ganja. Hasil penelitian ini berguna bagi pengelola kesehatan gigi dan mulut sebagai informasi tambahan dalam merencanakan program penyuluhan mengenai kesehatan gigi dan mulut terhadap pecandu ganja dan mantan pecandu ganja dan juga sebagai bahan pertimbangan para dokter gigi dalam menangani pasien yang merupakan mantan pecandu ganja.

\section{BAHAN DAN METODE}

Jenis penelitian ini adalah observasional analitik dengan rancangan penelitian cross sectional yang dilakukan pada Januari 2014 sampai Mei 2014 di Panti Sosial Parmadi Putra (PSPP) Insyaf Medan. Populasi adalah pecandu ganja yang sedang menjalani proses rehabilitasi di PSPP Insyaf Medan tahun 2014. Kriteria inklusi pecandu ganja adalah laki-laki berusia 16-49 tahun, konsumsi ganja terakhir kurang dari satu tahun sebelum penelitian dilakukan, sedang menjalani masa rehabilitasi dan bersedia untuk berpartisipasi dalam penelitian. Kriteria eksklusi pecandu ganja yang memiliki masalah kesehatan (dalam masa medical outing) dan memiliki gangguan kesehatan mental. Jumlah sampel adalah 40 orang yang diambil secara purposive sampling, terdiri atas 30 mantan pecandu ganja dan 10 mahasiswa FKG USU tanpa riwayat konsumsi ganja berusia 20-24 tahun sebagai kelompok kontrol. Kontrol berjumlah 10 sampel karena rata-rata pecandu ganja berkisar 10 orang apabila dibagi kedalam kelompok berdasarkan frekuensi, durasi dan lamanya mengonsumsi ganja. Ethical Clearance diperoleh dari Komisi Etik Penelitian Bidang Kesehatan FK Universitas Sumatera Utara.

Subjek diminta mengisi kuesioner selanjutnya diberi penjelasan mengenai tujuan, manfaat dan prosedur penelitian yang akan dilakukan dan apabila subjek bersedia untuk berpartisipasi dalam peneliti- 
an maka diminta menandatangani lembar informed consent. Subjek yang memenuhi kriteria inklusi diinstruksikan untuk tidak mengonsumsi apapun setelah sarapan dan dua jam kemudian subjek diminta untuk mengunyah ortho wax selama 5 menit dan mengumpulkan saliva secara berkala dengan metode spitting ke dalam pot saliva yang telah diberi label. Sampel saliva kemudian di timbang dengan timbangan digital dan dikurangi dengan berat pot saliva kosong untuk mengetahui volume saliva.

Analisis data dilakukan dengan komputer menggunakan Uji T tidak berpasangan untuk melihat rerata volume saliva yang distimulasi pada kelompok mantan pecandu ganja dan kelompok kontrol dan uji oneway Anova untuk melihat hubungan frekuensi, durasi dan lamanya mengonsumsi ganja dengan volume saliva yang distimulasi pada kelompok mantan pecandu ganja dan kelompok kontrol.

\section{HASIL}

Volume saliva terstimulasi pada kelompok mantan pecandu ganja lebih rendah apabila dibandingkan dengan kelompok tanpa riwayat mengonsumsi ganja (kontrol). Ada perbedaan volume saliva (stimulasi) yang signifikan antara kelompok mantan pecandu ganja dengan kelompok kontrol dengan nilai $\mathrm{p}<0,05$ (Tabel 1).

Tabel 1. Rerata volume saliva yang distimulasi pada kelompok mantan pecandu ganja dan kelompok kontrol

\begin{tabular}{cccc}
\hline Kelompok & $\mathrm{n}$ & Rerata Volume Saliva & $\mathrm{p}$ \\
\hline Mantan pecandu ganja & 30 & $7,7623 \pm 3,16361$ & \\
\cline { 1 - 3 } Kontrol & 10 & $10,1500 \pm 2,35816$ & \\
\hline
\end{tabular}

Subjek yang mengonsumsi ganja lebih dari lima kali per minggu masih memiliki efek terhadap terjadinya penurunan volume saliva. Semakin sering seseorang mengonsumsi ganja maka semakin turun volume salivanya (Tabel 2).

Subjek yang mengonsumsi ganja lebih dari delapan tahun masih memiliki efek terhadap terjadinya penurunan volume saliva. Semakin lama seseorang mengonsumsi ganja maka semakin turun volume salivanya (Tabel 3).

Subjek yang telah berhenti mengonsumsi ganja kurang dari empat bulan masih memiliki efek terhadap terjadinya penurunan volume saliva. Semakin lama seseorang berhenti mengonsumsi ganja maka efek yang menyebabkan penurunan volume saliva (stimulasi) akan semakin berkurang (Tabel 4).
Tabel 2. Hubungan frekuensi konsumsi ganja dengan volume saliva yang distimulasi pada kelompok mantan pecandu ganja dan kelompok control

\begin{tabular}{ccccc}
\hline Kelompok & $\mathrm{n}$ & $\begin{array}{c}\text { Rerata Volume } \\
(\mathrm{ml} / 5 \mathrm{menit}) \pm \mathrm{SD}\end{array}$ & $\mathrm{p}$ \\
\hline Kontrol & 10 & $10,1500 \pm 2,35816$ & \multirow{2}{*}{0,714} \\
\cline { 1 - 3 } 1-4 kali/minggu & 12 & $9,7417 \pm 3,34637$ & \\
\hline Kontrol & 10 & $10,1500 \pm 2,35816$ & \multirow{2}{*}{$0,044^{*}$} \\
\cline { 1 - 3 } 5-8 kali/minggu & 8 & $7,5825 \pm 2,11925$ & \\
\hline Kontrol & 10 & $10,1500 \pm 2,35816$ & \multirow{2}{*}{$0,049^{*}$} \\
\cline { 1 - 3 } 9-12 kali/minggu & 3 & $7,4300 \pm 2,92057$ & \\
\hline Kontrol & 10 & $10,1500 \pm 2,35816$ & \multirow{2}{*}{$0,020^{*}$} \\
\cline { 1 - 3 } 13-16 kali/minggu & 2 & $5,2650 \pm 0,75660$ & \\
\cline { 1 - 3 } Kontrol & 10 & $10,1500 \pm 2,35816$ & \multirow{2}{*}{$0,000^{*}$} \\
\hline$>16$ kali/minggu & 5 & $4,4980 \pm 1,07667$ & \\
\hline
\end{tabular}

Tabel 3. Hubungan durasi konsumsi ganja dengan volume saliva yang distimulasi pada kelompok mantan pecandu ganja dan kelompok kontrol

\begin{tabular}{cccc}
\hline Kelompok & $\mathrm{n}$ & $\begin{array}{c}\text { Rerata Volume } \\
(\mathrm{ml} / 5 \mathrm{menit}) \pm \mathrm{SD}\end{array}$ & $\mathrm{p}$ \\
\hline Kontrol & 10 & $10,1500 \pm 2,35816$ & \multirow{2}{*}{0,241} \\
\cline { 1 - 3 } 0 -4 tahun & 17 & $8,8476 \pm 3,31687$ & \\
\cline { 1 - 3 } Kontrol & 10 & $10,1500 \pm 2,35816$ & \multirow{2}{*}{0,253} \\
\hline 5-7 tahun & 4 & $8,2650 \pm 2,80928$ & \\
\cline { 1 - 3 } Kontrol & 10 & $10,1500 \pm 2,35816$ & \multirow{2}{*}{$0,038^{*}$} \\
\hline 8-10 tahun & 4 & $6,6450 \pm 1,62582$ & \\
\cline { 1 - 3 } Kontrol & 10 & $10,1500 \pm 2,35816$ & \multirow{2}{*}{$0,001^{*}$} \\
\hline$>10$ tahun & 5 & $4,5640 \pm 1,16577$ & \\
\hline
\end{tabular}

Tabel 4. Hubungan lamanya konsumsi ganja dengan volume saliva yang distimulasi pada kelompok mantan pecandu ganja dan kelompok control

\begin{tabular}{cccc}
\hline Kelompok & $\mathrm{n}$ & $\begin{array}{c}\text { Rerata Volume } \\
(\mathrm{ml} / 5 \mathrm{~m} \text { menit }) \pm \mathrm{SD}\end{array}$ & $\mathrm{p}$ \\
\hline Kontrol & 10 & $10,1500 \pm 2,35816$ & \multirow{2}{*}{$0,038^{*}$} \\
\hline 0-4 bulan & 21 & $7,6457 \pm 3,14298$ & \\
\cline { 1 - 3 } Kontrol & 10 & $10,1500 \pm 2,35816$ & \multirow{2}{*}{0,137} \\
\hline 5-9 bulan & 9 & $8,0344 \pm 3,38610$ & \\
\hline
\end{tabular}

\section{PEMBAHASAN}

Ganja mempengaruhi volume saliva akibat kandungan THC dalam ganja yang memiliki sifat parasimpatolitik. ${ }^{11}$ Reseptor "cannabinoid" secara umum berpasangan dengan protein $\mathrm{G}$ yang berada pada membran sel saraf parasimpatik. Hal ini dapat menyebabkan THC yang masuk ke dalam tubuh akan berikatan dengan protein $\mathrm{G}$ dan reseptor "cannabinoid", menginhibisi saluran ion kalsium dan mengaktivasi saluran potasium. Masuknya ion kalsium ke dalam sel di ujung sinaps diperlukan untuk proses eksositosis neurotransmitter dan aktivasi saluran potasium menyebabkan hiperpolarisasi sel sehingga sel pada saraf parasimpatik akan mengalami 
hambatan pada proses eksositosis. ${ }^{12}$ Dengan demikian, fungsi saraf parasimpatis terinhibisi dan sekresi saliva hanya didapat melalui sistem saraf simpatis yang menyebabkan terjadinya vasokonstriksi dan menurunnya aliran darah ke kelenjar saliva, sehingga sel asini mengalami atrofi dan menghasilkan saliva dengan volume yang lebih sedikit, kental dan mengandung lebih banyak musin. ${ }^{13,14}$

Penelitian Prestifilipo menemukan bahwa selain terdapat pada sistem saraf, otak dan sel imun, reseptor "cannabinoid" dapat juga ditemukan di kelenjar saliva yaitu pada sistem saluran kelenjar saliva (ductal system) dan pada sel asini. THC pada ganja akan bereaksi apabila berikatan dengan reseptornya sehingga ketika THC berikatan dengan reseptornya yang berada pada kelenjar submandibula selama stimulasi elektrik maka dapat terjadi penurunan pengeluaran asetilkolin yang merupakan postganglionic transmitter saraf parasimpatis sehingga terjadi reduksi sekresi saliva. ${ }^{4,8,14}$ Penelitian Katterbach menyatakan bahwa $84 \%$ dari pecandu ganja mengalami mulut kering dan $91 \%$ merasa haus setelah mengonsumsi ganja. Hal ini menunjukkan bahwa terjadi hiposalivasi pada pecandu ganja. ${ }^{8,15}$

Frekuensi mengonsumsi ganja lebih dari lima kali per minggu yang memiliki efek cukup kuat dalam menyebabkan penurunan volume saliva (stimulasi) bahkan setelah pecandu ganja sudah tidak lagi mengonsumsi ganja (Tabel 2). Semakin sering seseorang mengonsumsi ganja maka semakin THC yang masuk ke dalam tubuh terjadi secara terus-menerus, sehingga efek vasokonstriksi pembuluh darah pada kelenjar saliva yang menyebabkan atrofi pada sel asini terjadi terus-menerus. Hal ini mengakibatkan sulit berlangsungnya proses pemulihan akibat atrofi sel asini tersebut. Semakin sering seseorang mengonsumsi ganja maka semakin lama efek penurunan volume saliva pada mantan pecandu ganja. . $^{12-16}$

Durasi mengonsumsi ganja lebih dari sepuluh tahun yang memiliki efek cukup kuat dalam menyebabkan penurunan volume saliva (stimulasi) bahkan setelah pecandu ganja sudah tidak lagi mengonsumsi ganja. Hasil pada penelitian ini sesuai dengan teori yang menyatakan bahwa defisit fungsi fisiologis termasuk fungsi sekresi akibat atrofi sel asini pada pecandu ganja tergantung pada jumlah ganja ataupun dosis yang biasa dikonsumsi. Dimana jumlah atau dosis mengonsumsi ganja dipengaruhi oleh frekuensi dan durasi dalam mengonsumsi ganja. ${ }^{11,15,16}$ Dalam penelitian ini diketahui juga bahwa semakin banyak ganja yang dikonsumsi maka semakin lama efek penurunan volume saliva pada mantan pecandu ganja.

Kelompok yang telah berhenti mengonsumsi gan- ja selama kurang dari empat bulan yang masih memiliki efek dalam menyebabkan penurunan volume saliva (stimulasi). Hal ini dapat terjadi karena kandungan THC dalam ganja bersifat lipofilik sehingga eliminasi THC dari dalam tubuh berlangsung cukup kompleks dan membutuhkan waktu yang cukup lama. THC berakumulasi di jaringan adiposa selama lima sampai tujuh hari dan secara perlahan dikeluarkan lagi ke tubuh. THC diekskresikan 25\% melalui urin dan $65 \%$ ke dalam usus untuk di reabsorbsi sehingga efek samping dari THC dapat bertahan lebih lama. ${ }^{7}$ Kerusakan yang terjadi pada sistem saraf, saluran kelenjar saliva submandibula dan sel-sel asini kelenjar saliva submandibula yang dapat mempengaruhi terjadinya penurunan volume saliva (stimulasi) pada pecandu ganja dapat terjadi terus menerus apabila pecandu ganja selalu mengonsumsi ganja., ${ }^{479}$ Dan kerusakan tersebut dapat bertahan bahkan setelah pecandu ganja berhenti mengonsumsi ganja. Lamanya perbaikan yang terjadi pada kerusakan tersebut bergantung pada usia ketika mengonsumsi ganja, lamanya mengonsumsi ganja, dan jumlah ganja yang digunakan. ${ }^{16}$

Dari hasil penelitian diketahui bahwa pecandu ganja memiliki volume saliva yang berkurang. Volume saliva yang berkurang mengakibatkan rendahnya self cleansing dan fungsi imun dalam menjaga kesehatan rongga mulut. Sehingga pada pecandu ganja dapat terjadi peningkatan jumlah bakteri dan jamur pada rongga mulut, termasuk bakteri anaerob dan Candida albicans. Akibat oral higiene yang kurang baik maka sering terjadi karies pada para pecandu ganja. Menurut penelitian Ditmyer memberitahukan bahwa terjadi peningkatan prevalensi dan keparahan karies pada pecandu ganja dimana pecandu ganja memiliki jumlah DMFT (decay, missing, filling teeth) dua kali lebih tinggi dibanding perokok biasa. ${ }^{17}$ Pembentukan plak gingiva dan meningkatnya koloni bakteri anaerob dapat meningkatkan terjadinya gingivitis pada pecandu ganja. 18,19

Karena seringnya terjadi gangguan kesehatan gigi dan mulut tersebut maka perlu perhatian dari dokter gigi dalam menangani pasien yang merupakan pecandu ganja ataupun mantan pecandu ganja. Semakin lama seseorang berhenti mengonsumsi ganja, volume saliva dapat kembali mendekati normal, oleh sebab itu perlu pemeriksaan berkala pada kesehatan gigi dan mulut mantan pecandu ganja terutama selama berada di dalam Pusat Rehabilitasi agar dapat juga diawasi oleh petugas rehabilitasi.

Dapat disimpulkan bahwa ada hubungan mengonsumsi ganja dengan penurunan volume saliva yang distimulasi antara kelompok mantan pecandu ganja dibandingkan dengan kelompok kontrol dan hal ini dipengaruhi oleh frekuensi, durasi dan lama- 
nya berhenti mengonsumsi ganja. Perlu penelitian selanjutnya mengenai efek langsung konsumsi ganja pada saliva pada subjek yang masih mengonsumsi ganja dengan menggunakan jumlah sampel yang sama di tiap kelompok.

\section{Daftar Pustaka}

1. United Nations Office on Drugs and Crime. World Drug Report 2012. <http: //www. unodc.org/ documents/data-and-analysis/ WDR2012 WDR_ 2012 _web_small.pdf> (28 Juli 2013).

2. Nurhidayat A, Amir N, Susami H, Brink W, Metzger D. Drug abuse and AIDS in Indonesia: from research to drug policy and treatment. <https:// www.jspn.or.jp/ journal/ symposium/ pdf/ jspn108/ ss429-432.pdf> (28 Juli 2013).

3. Badan Narkotika Nasional Republik Indonesia. Data tindak pidana narkoba provinsi sumatera utara tahun 2007-2011. <http:// bnn.go.id/ portal/_up-loads/ post/ 2012/05/10/20120510170025-10251. pdf> (10 Maret 2014).

4. Burkhat NW. Marijuana. 2010. http:// www. rdhmag. com/articles /print/ volume-30/issue-8/ columns/marijuana.html. (1 Agustus 2013).

5. William, M. The significance of illicit drug use to dental practice. <http:// www. webmedcentral. Com /article_view/455> (18 Juli 2013).

6. William, M. Significance of cannabis use to dental practice. N Y State Dent J 2011: 36-9.

7. Cho CM, Hirsch R, Johnstone S. General and oral health implications of cannabis use. Aus Dent $\mathrm{J}$ 2005: 50 (2): 70-4.

8. Prestifilippo JP, Solari JF, Cal CDL, Iribarne M, Suburo AM, Rettori V, et al. Inhibition of salivary secretion by activation of "cannabinoid" receptors. Exp Biol Med 2006; (231): 1421-9.
9. Kopach O, Vats J, Netsyk O, Voitenko N, Irving A, Fedirko N. "cannabinoid" receptors in submandibular acinar cells: functional coupling between saliva flyid and electrolytes secretion and $\mathrm{Ca}^{2+}$ signalling. J Cell Sc 2011; 125: 1884-95.

10. Jose, Maji. Essentials of oral biology. New Delhi: CBS Publishers, 2010: 284-8.

11. Veitz-Keenan A, Ferraiolo D. Cannabis use and xerostomia. 〈http:// www. dimensions ofdentalhygiene.com/ddhright.aspx?id=11935>（19 Agustus 2013).

12. Pacher P, Batkai S, Kunos G. The endo"cannabinoid" system as an emerging target of pharmacotherapy. Pharmacol Rev 2006; 58: 389-462.

13. Ekstrom J, Khosravani N, Castagnola M, Messana I. Saliva and the control of its secretion. J Physiol Pharmacol 2009; 62: 95-9.

14. Tortora GJ, Derrickson B, Principle of anatomy and physiology. Washington DC: John Wiley and Sons Inc, 2006: 1046-8.

15. Schulzkatterbach M, Imfelt T, Imfelt C. Cannabis and caries - does regular cannabis use increase the risk of caries in cigarette smokers. Schweiz Monatschr Zahnmed. 2009; 119: 576-83.

16. Crean RD, Crane NA, Mason BJ. An evidencebased review of acute and long-term effects of cannabis use on executive cognitive functions. J Addict Med 2011; 5: 1-8.

17. Ditmyer M, Demopoulos C, McClain M, Dounis G, Mobley C. The effect of tobacco and marijuana use on dental health status in nevada adolescents: a trend analysis. J Adolesc Health 2012; 52(2013): 641-8.

18. Hurlbutt M, Novy B, Young D. Dental caries: a pHmediated disease. Can Dent Hyg J 2010; 25(1): 9-15.

19. Veersteeg PA, Slot DE, Van der VU, Van der WGA. Effect of cannabis usage on the oral environment: a review. Int J Dent Hyg 2008; 6: 315-20. 